\title{
Resources Capability of Government Co-operative Supporting Organizations for Innovations Dissemination to Primary Co-operative Societies in Tanzania
}

\author{
Luka S. Njau \\ lukasnjau@yahoo.co.uk| Department of Development Studies, College of Social Sciences and \\ Humanities, Sokoine University of Agriculture, P. O. Box 3024, Morogoro, Tanzania \\ Christopher P. Mahonge \\ mahonge@sua.ac.tz | Department of Policy Planning and Management, College of Social Sciences and \\ Humanities, Sokoine University of Agriculture, P. O. Box 3035, Morogoro, Tanzania \\ Fatihiya A. Massawe \\ mnkya74@gmail.com | Department of Policy Planning and Management, College of Social Sciences and \\ Humanities, Sokoine University of Agriculture, P. O. Box 3035, Morogoro, Tanzania
}

\begin{abstract}
This study assessed resources capability of government co-operative supporting organizations (GCSOs) in innovations dissemination to primary co-operative societies (PCSos) in Tanzania. Case study research design using multiple cases was used involving five cases. Primary data were collected using key informant interviews, focus groups discussions (FGDs), documentary reviews and personal observations. Data were analysed using content analysis. The Atlas.ti computer software assisted in analyzing data solicited from key informants and FGDs. Findings indicate that most GCSOs in Tanzania were poor in terms of resources to disseminate innovations to PCSos. Most GCSOs were also not determined at prioritizing and utilizing available resources for dissemination of innovations to PCSos. Furthermore, some external factors e.g. inadequate government resources commitment, employment freezing and others have been adversely affecting GCSOs resources capability to disseminate innovations to PCSos. Moreover, there were no formal and comprehensive incentive systems to reward innovation dissemination activities in most of the GCSOs. It is recommended that GCSOs executives should mobilise more internal resources and ensure sufficient innovation resources prioritisation and utilization to adequately facilitate innovations dissemination to PCSos. The GCSOs executives should also establish clear incentive systems to reward innovation dissemination activities.
\end{abstract}

Keywords. Government Co-operative Supporting Organizations; Resources Capability; Innovations Dissemination; Primary Co-operative Societies.

Cite paper as: Njau, L., Mahonge, C., Massawe, F., (2019). Resources Capability of Government Co-operative Supporting Organizations for Innovations Dissemination to Primary Co-operative Societies in Tanzania, Journal of Innovation Management, www.open-jim.org, 7(4), 77-105.

ISSN 2183-0606

http://www.open-jim.org

http://creativecommons.org/licenses/by/3.0 


\section{Introduction}

Organizations require resources as inputs to become innovative and competitive (Goedhuys, Janz \& Mohnen, 2014). Thus, resources are as important to organizations as is blood in human body. Organizational resources refer to assets/inputs which an organization owns, controls and has access to for the purpose of facilitating its day to day activities (Piening, 2013). However, possessing such inputs does not automatically lead to creation of value (Ndofor, Sirmon \& He, 2015; Sirmon, Hitt \& Ireland, 2007). Organizations must therefore be able to accumulate, combine and exploit resources in order to extract value from them (Grant, 1991). This paper intends to assess the resources capability of Government Co-operative Supporting Organizations (GCSOs) for dissemination of innovations to Primary Co-operative Societies (PCSos). There are several categories of resources. Classical economics recognizes three basic categories of resources, also referred to as factors of production: land, labour and capital (Gaffney, 1967). Entrepreneurship is often considered the fourth factor of production (Turtle, 1927). Other categorization includes natural (renewable and non renewable) and human (structures, institutions, quantity and quality) resources (Lamon, 2014). Another categorization is based on the biotic resources including all resources obtained from biosphere and have life e.g. human beings, flora and fauna, fisheries, etc and abiotic resources composed of non-living things e.g. rocks, metals, etc (Cbsemocha, 2013). This paper adopts the categorization of resources from Christensen (1997) who grouped them into physical, human, financial and technological resources. Barney (1991) indicates that an organization will attain innovations if it possesses and allocates its resources on the same. Organizational resources capability is therefore directly related to the search for, absorption and generation of innovations (Srholec, 2011).

Innovation has long been cited as essential for organizational competitiveness and success (Bekkers, Edelenboss \& Steijen, 2011; Edwards, Delbridge \& Munday, 2005). This awareness has generated a great deal of literature on the subject matter. As a result, innovation has become an extensive concept that can be perceived in a number of different ways (Smith, Bursi, Ball $\&$ van dee Meer, 2008). Osborne (1998) indicated that there are over 20 different definitions of the term innovation. The World Bank (2006) defined innovation as the process by which individuals or organizations master and implement the design and production of goods and services that are new to them, irrespective of whether they are new to their competitors, their country or the world. This paper adopts a modified version of this definition that regards innovation as the process by which government organizations, in this study, the co-operative supporting organizations, creates and offers goods and services that are new to them, including changes in an old or existing way of doing things, irrespective of whether they are new to their competitors, their country or the world, which are intentionally directed at improving targeted end users i.e. primary co-operatives performance. In this case, the public or private sector organizations are faced with only two options: innovate or perish (Mathew, Jose \& Thomas, 2006). Most public organizations in developing countries operate below the technology frontier with lower levels of managerial and production skills (Goedhuys and Sleuwaegen, 2010) resulting from organization's resource inadequacies (Bradley, McMullen, Artz \& Simiyu, 2012; George, Gorbishley, Khayesi, Haas \& Tihanyi, 2016). Despite this shortfall, some of such organizations have been playing a key role in developing and disseminating innovations (Barasa, Knoben, Vermeulen, Kimuyu 
\& Kinyanjui, 2017). In most of the developing countries, there are several government support organizations that have been established and financed by the government for the purpose of facilitating innovations dissemination from where the innovations are produced to the targeted users (Tefera, 2008). Among such government organizations, in Tanzania, are the government co-operative supporting organizations - referred to as government institutions responsible for facilitating co-operative organizations in terms of innovations creation and dissemination, education and training, promotion, regulation, production, marketing, etc. The organizations include the Moshi Co-operative University (MoCU), Tanzania Co-operatives Development Commission (TCDC), Office of the Director and Registrar of Co-operatives (ODRC-transformed into TCDC in 2013), Small Industries Development Organization (SIDO), Co-operative Audit and Supervision Corporation (COASCO), Tanzania Research Institutes e.g. Tanzania Coffee Research Institute (TaCRI), Vocational Education and Training Authority (VETA) among others.

\subsection{Conceptualization of the problem}

The co-operatives, particularly the Primary Co-operative Societies (PCSos), have been an important part in the development of Tanzania for nearly nine decades now. During this period, they have seen many successes in terms of increased incomes and social benefits to members and community at large (Chambo, 2018). They have also experienced many failures resulting from mismanagement, embezzlement, weakness of supporting organizations, state interference, inability to compete in free market economy and general lack of co-operative education. During such period, however, no other institution has brought so many people together for a common cause than PCSos (Borda-Rodriguez, 2014; Chambo, 2018; United Republic of Tanzania [URT], 2006). Co-operatives salient features i.e. member owned and controlled organizations and attribute of involving the poor and weak members who have always been on the sidelines of rural and urban mainstream economy has attracted the attention of many governments and organizations into their support in terms of resources (Chambo, 2018). It is from such recognition that the government of Tanzania has established and facilitated operations of several GCSOs for the purpose of facilitating PCSos growth and development.

Most of these GCSOs have continued to attract resources from the government in terms of skilled manpower, finances and other resources like vehicles, land, technological facilities, etc to meet operational costs, staff salaries, infrastructural demands and implementation of research agenda $(\mathrm{R} \& \mathrm{D})$. All these efforts target at facilitating PCSos in areas of innovations creation and dissemination, production, marketing, education and training, etc. This study focused solely on innovations dissemination referred to as intentional spreading of innovations from the source to targeted audience (Lomas, 1993). This is because, in the context of this paper, innovation dissemination is considered to be an important node that links innovation sources (GCSOs) and targeted users (PCSos). Likewise, innovation was considered to be underdeveloped in most public organizations in Tanzania and hence necessitates assessing its dissemination in specific organizations.

Despite government resources support to GCSOs, empirical literature has indicated that few innovations are disseminating to PCSos in Tanzania (International Co-operative Alliance [ICA], 2013; URT, 2006; World Bank, 2012). As a result, significant number of co-operatives in Tanza- 
nia currently totalling 8,040 has been denied access to necessary innovation packages that could be disseminated from such organizations (URT, 2016). This study posits that the government is supposed to support GCSOs by providing them with resources to enable among other activities, innovations dissemination to PCSos, and thus many innovations are expected at PCSos level. Contrary to such expectations few innovations have been disseminated from GCSOs to PCSos in Tanzania (ICA, 2013; URT, 2006). This paper argues that having resources alone may not necessarily lead to innovations dissemination to PCSos and perhaps there is potentially existence of other factors limiting innovations dissemination from GCSOs to PCSos. Resources are an important determinant of innovations dissemination in most organizations (Bradley et al., 2012; Laursen, Masciarelli \& Principe, 2012; van Uden, Knoben \& Vermeul, 2017). However, possessing resources alone is not enough to enable innovations dissemination (Barasa et al., 2017; Ndofor et al., 2015). This is because; organizations' innovation resources capability is influenced by other complementary forces (Barasa et al., 2017). The key ones include the organizations' determination to prioritize and utilize available resources for innovation (Srholec, 2011), innovation incentives available (Johnson \& Lybecker, 2009) and external factors influencing innovation (Patana, 2014). Studies have shown that insufficient resources prioritization and utilization for innovation activities is a problem inherent in many public organizations in Tanzania (Diyamett \& Wangwe, 2006; DFID, 2014). Nevertheless, scant literature is available on the extent to which GCSOs in Tanzania have been prioritizing and utilizing their resources for innovation dissemination to PCSos. Available literature indicated that most public organizations have been prioritizing and utilizing most of its resources in activities other than innovations (Sambua and Mghwira, 2014; World Bank, 2016). This shortfall thus lands us on the first question: How do the innovation resources prioritization and utilization occur in the studied GCSOs? This paper argues that few innovations dissemination originating from GCSOs to PCSos in Tanzania are a consequence of lack of determination by GCSOs executives to prioritize and/or utilize available resources to enable innovations dissemination to PCSos. Similarly, empirical literature has indicated that effective innovations dissemination does not occur at its own sake instead there should be incentives behind it (Johnson \& Lybecker, 2009). Incentive is defined as a thing that motivates or encourages someone to do something. It includes payment or concession to stimulate greater output or investment (Oxford dictionary online, 2001). Johnson \& Lybecker (2009) indicate that innovations dissemination responds quickly to incentives in place. Incentives like performance reviews, funds, promotions or simply getting recognition of what has been done, increase the likelihood for successful innovations dissemination (Damschroder, Aron, Keith, Alexander \& Lowery, 2009). Studies have shown that there is association between incentives and resources utilization capability (Hollander and Kadlec, 2015; Murphy et al., 2016). In Tanzania, however, literature on the linkages between incentives available and GCSOs resources capability to disseminate innovations to PCSos are nonexistent. This deficit therefore, lands us to the second question: Are there incentive systems in place to reinforce the GCSOs skilled workforce to disseminate innovations to PCSos? The argument put forward in this paper is that inadequate incentives to activate GCSOs operatives is among the reasons as to why few innovations are disseminated from GCSOs to PCSos in Tanzania.

On the other hand, external factors like government innovation policy focus and its related regulations, innovation resources commitment, directives and others can influence GCSOs resources capability to disseminate innovations to PCSos. The well enforced, coordinated and affirma- 
tive government innovation policy and related regulations can potentially facilitate innovations dissemination (Barasa et al., 2017; Patana, 2014; United Nations Conference on Trade and Development [UNCTAD], 2015). However, literature has shown that most developing countries lack organizations and institutions to regulate and coordinate innovation activities (OyelaranOyeyinka, 2014). Similarly, the Department for International Development [DFID], 2014) and UNCTAD (2015) review of Science, Technology and Innovation (STI) policy in Tanzania established existence of incoherence and lack of coordination between STI policy and other government organizations, lack of government resources commitment and inadequate collaboration among innovation actors as the factors limiting innovation activities. However, it is not well known on how such external factors are specifically influencing GCSOs resources capability to disseminate innovations to PCSos in Tanzania. Available literature generally shows that the country suffers inherently from a lack of innovation policy focus and co-ordination among its actors (Diyamett \& Wangwe, 2006; DFID, 2014; UNCTAD, 2015). The shortfall thus lands us to the third question: How do the external factors influence GCSOs resources capability to disseminate innovations to PCSos? The argument put forth by this paper is that few innovations disseminating from GCSOs to PCSos is a result of limiting external factors. The combination of the three arguments posed in this paper, necessitates the assessment of the GCSOs resources capability in innovations dissemination to PCSos.

\section{Theoretical Review}

This paper draws insights from two theories; the Resource Dependence (RD) Theory (Pfeffer \& Salancik, 1978) and the Carrot and Stick (C \&S) Theory (Bowring, 1962; Hixson, 1989). The first theory examines the relationship between organizations and the resources they need to operate. The main argument in this theory is that when one organization possess or maintains the majority of the resources, then another organization will become dependent on the one possessing such resources in order to operate. This scenario creates a dependence syndrome (parasitic kind of) to the organization that depends on such resources. This implies that when the government maintains the majority of resources and the GCSOs maintain too little resources then the GCSOs become symbiotically dependent on the government. Continued and too much dependence creates unreliability which leaves such organizations subject to risk of external control. Such external control basically imposed by the government can have significant effects on GCSOs operations especially on resources capability. The theory thus requires managers to work and strive in strategising in alternative business plans or activities to lower the dependence risk. This implies that the managers in this study the GCSOs executives should work to reduce the resources dependence risk or syndrome for the purpose of lowering the innovations dissemination failure. This study applies the theory in assessing the relationships between GCSOs and the government in terms of innovation resources availability to facilitate innovations dissemination to PCSos. The theory is nevertheless criticized for most of its empirical work focusing on dependence of one actor on another rather than on reciprocal interdependence (Hillman, Withers \& Collins, 2009). The second theory i.e. C\&S Theory also known as Reward and Punishment Approach is based on the principles of reinforcement. It asserts that in motivating people to elicit desired behaviors, sometimes rewards should be given in form of financial or non financial 
benefits and sometimes punishment should be exerted to push such people towards the desired behavior. The study applied the theory in ascertaining whether there are any formal incentives or reward and punishment systems pertaining to innovations dissemination activities in the studied GCSOs. In this study, the term formal incentive system was used to mean clearly stipulated, documented and adhered motivational arrangement. It is assumed that for innovations dissemination to PCSos to occur, there should be some incentives and or reinforcements from either the government or GCSOs to motivate personnel to do so. The C \& S Theory however, is critiqued that, widespread use of tangible rewards or punishments as motivators do not promote intrinsic motivation (Restrepo \& Valencia, 2014). The two theories i.e. the RD Theory and C \& $\mathrm{S}$ Theory complement each other deriving from the possibilities that the problems of innovations dissemination to PCSos can be within and beyond the reach of GCSOs.

\section{The Conceptual Framework (CF)}

As shown in Fig. 1 it is assumed that innovations dissemination from GCSOs to PCSos is a function of resources availability, GCSOs determination to prioritize and utilize available resources for innovation, external factors influence and innovation incentives in place. This means that resources availability in form of skilled man power, funds, appropriate technologies and

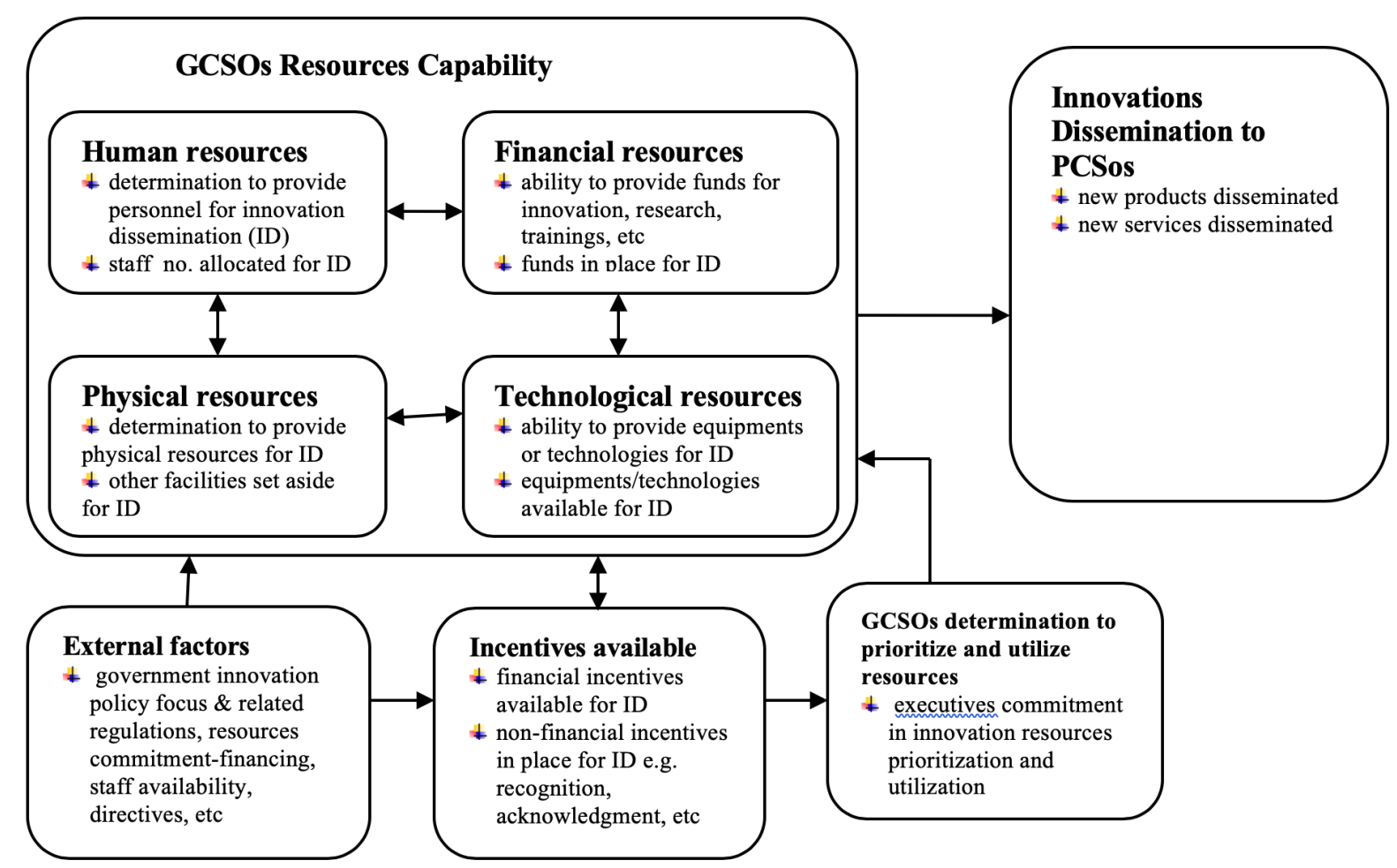

Fig. 1. The CF Summarizing Relationships between GCSOs Resources Capability and Innovations Dissemination (ID) to PCSos (Source: Own Construction) 
physical facilities e.g. land, innovation incubators, workshops and laboratories can positively influence innovations dissemination. Nevertheless, availability of resources alone is not sufficient to enable effective dissemination of innovations. This is because having resources alone does not necessarily mean that they will be directed at enabling innovation dissemination activities. Thus, there should be determination or willingness by GCSOs executives to prioritize and utilize such resources to facilitate innovations dissemination to PCSos. Moreover, the availability of the resources can be influenced by some external factors. The well organized and assenting external factors to innovation including government innovation policy focus and its related regulations, innovation resources commitment e.g. financing and personnel commitment and affirmative government directives activate GCSOs resources base by capacitating it to disseminate innovations to PCSos. Equally, innovation incentives from either the government or GCSOs in form of recognition of innovation activities performed, financial rewards, promotions, training opportunities and others can activate GCSOs' operatives to actively participate in innovations dissemination to PCSos.

\section{Methodology}

\subsection{The Study Areas and Scope}

The study was conducted in three regions i.e. Kilimanjaro, Dar es Salaam and Dodoma where the key GCSOs are located i.e. MoCU and TaCRI, SIDO and VETA and TCDC respectively. The study focused only on GCSOs, though there are other private and member-based organizations that support PCSos. The rationale for focusing on the GCSOs is that unlike other organizations, they have been receiving resources from government aiming at, among other activities, strengthening co-operatives. Equally, they are mandated by the law to reinstate competitive and innovative co-operatives in the country (URT, 2013).

\subsection{Research Design and Data Sources}

The case study research design using multiple case studies (MCS) was used. Given the varying primary mandates of selected cases, theoretical replication was assumed implying that cases were selected on the assumption that they will produce differing results (Bengtsson, 1999). MCS follow the replication and not the sampling logic approach. This means that more than two cases i.e. five cases were included in this study to enable comparisons and drawing patterns across the cases and obtaining more reliability in the overall results (Yin, 2004). Multiple cases increase the methodological rigor by strengthening the precision, the validity and reliability of findings (Miles \& Huberman, 1994) making it more compelling (Yin, 1994). It also ensures generalization of the findings i.e. analytic generalization as opposed to statistical generalization.

Sources of data constitute GCSOs documents e.g. strategic plans and innovation policy documents, key informants (KIs) constituting the GCSOs executives, some heads of departments/units and staff responsible for innovation activities, FGDs participants involving GCSOs heads of departments/units and staff and direct observation e.g. innovation facilities in place. A total 
of 14 FGDs, three per each GCSO were conducted except for TaCRI where two FGDs were conducted mainly due to data saturation realization. Several FGDs were conducted in the same GCSO aiming at soliciting more facts and verifying some data. The number of focus groups depend on the amount of facts needed (McDougall and Fudge, 2001). Most studies use at least two groups and few use more than four groups (Stewart, Shamdasani \& Rook, 2007). Each focus group comprised of 6-8 participants. There are no definitive numbers of focus group participants. However, Stewart et al. (2007) emphasized that FGD should comprise of 6-12 participants since fewer than six tends to reveal less information and can be dull. Likewise, too many participants may be difficult to manage. Similarly,the KIs educational and working experience profiles were established for the purpose of establishing their capability and or skills relative to the subject matter under investigation i.e. organizations' resources capability for innovations dissemination. The tools for data collection included: FGDs guide, key informants (KIs) interview guide, observation guide and an audio recorder where consent from study participants was sought before recording them.

\section{GCSOs' ratings and harmonization of the participant's responses}

In this study, the responses that require organization rating were first collected from specific participants. Then to harmonize some differing opinions from different study groups of the same GCSO, validation meetings comprised of participants from all groups were conducted. The standardized scale and criteria for rating the specific GCSO was used where it was clarified and agreed upon by study participants prior the actual validation meetings.

\section{Study Participants}

The units of analysis for this study were the GCSOs. A total of five GCSOs, two purely cooperative supporting organizations i.e. MoCU and TCDC and three quasi co-operative based i.e. SIDO, VETA and TaCRI were picked for the study. Purely co-operative based GCSOs refer to those whose primary mandate is to serve co-operatives and the vice-versa is true for the quasi co-operative based GCSOs. In the course of their undertakings, quasi co-operative based organizations deal with co-operatives as one among their key actors. The rationale for such number and categorization is that the study aimed at capturing data from all forms of GCSOs based on their prime functions. Equally, since the study involved MCS strategy, five cases identified by research scope were sufficient to provide the necessary data (Yin, 2004). The study participants were all heads of technical and academic departments/units and at least two staff from each department/unit that were conversant with innovation activities.

\section{Data Analysis}

Content analysis was used to analyze data obtained from the key informants (KIs) and FGDs. Data collected through recording and field notes were transcribed prior to its analysis. First, the responses and opinions of the interviewees were coded. Second, data were categorized, where a data base for categorizing, sorting and retrieving data was prepared. The categorization was done according to the topics in the interview guide and also the research objectives. In the third step, the categorized data were analyzed and this was done in three stages viz. reduction of data (i.e. selecting, simplifying and transferring raw data to an analyzable format), displaying the data and drawing research conclusion (Taylor, Sinha \& Ghoshal, 2011). The fourth step was 
documenting the case studies sets in form of qualitative descriptions and interpretations. The Atlas.ti computer software facilitated the analysis of data solicited from KIs and FGDs.

\section{Findings and Discussion}

\subsection{Profiles of the studied GCSOs}

MoCU is a public organization with its headquarters in Moshi Town in Kilimanjaro Region. It has one teaching centre in Kizumbi, Shinyanga Region and 15 regional offices for outreach services provision throughout mainland Tanzania. Its key mandates include providing education, training, research and advisory services to enhance co-operative development and other development affairs. It trains skilled co-operative practitioners, technocrats and managers at various levels including certificates, diploma, bachelors and postgraduate levels. Equally, the TCDC is a public organization headquartered in Dodoma city with key mandates of regulating and promoting co-operative sector in Tanzania. It promotes, provide education and training and facilitate development of co-operatives. Moreover, it regulates co-operatives i.e. register, deregister and provides legal advices to co-operatives among other legal issues. TCDC has regional and district level offices manned with regional and district co-operative officers in all regions of Tanzania.

On the other hand, TaCRI is a public-private entity headquartered in Lyamungu Village in Moshi Rural District. It has six sub-stations i.e. Lyamungu, Kilimanjaro, Maruku, Kagera, Mwayaya, Kigoma, Sirari, Mara, Mbimba, Mbeya and Ugano, Ruvuma. Its core functions include providing coffee producers with relevant practical technological innovations and advise to improve productivity and quality for enhanced productivity and livelihoods of coffee producers. SIDO is a public organization with its headquarters in Dar es Salaam city. SIDO has a regional office in all regions of mainland Tanzania. Its core mandates includes technology innovation and commercialization, technology and product development, incubator services, artisan support programmes and other related roles.

Similarly, VETA is a public organization with its headquarters in Dar es Salaam City. It operates its functions through nine geographical zones to enable effective coordination of vocational education and training in different regions. They include Dar es Salaam zone, Central, Lake, Western, South West, South East, Eastern, Highlands and Northern zone. Its core functions are to provide, coordinate, regulate and promote vocational education and training in Tanzania. It provides training through 27 training centres and institutes that it owns. It also offers vocational teachers training at its college in Morogoro Region. Given their strategic regional and or zonal centres and core mandates, some explicitly focusing on innovation activities, studied GCSOs were assumed to be resourcefully capable in disseminating innovations to PCSos.

Four of the five aforementioned GCSOs are public organizations while TaCRI is a public-private organization owned by stakeholders it serves. It was necessary to study both categories as they have all been receiving some resources mainly financing from the government. Its inclusion provides a proportional ground on their resources capability for innovations dissemination to PCSos. 


\subsection{Key Informants (KIs) Education and Experience}

The KIs education and working experience profile was established for the purpose of establishing their capability and or skills in relation to studied organization's resources capability for innovations dissemination. The study revealed the adequate level of formal education to most of the interviewed KIs. The majority of them had a minimum of bachelor's degree education whereby very few were diploma holders while others had postgraduate education i.e. masters and doctorates (PhDs). Most of the KIs were also having sufficient working experience with co-operative organizations and or related organizations. Regnar et al. (2002) emphasized that the ultimate objective of education is to increase labour productivity and thus it is a productive factor that is crucial for one's ability to utilize efficiently various resources that are available in a certain organization. This implies that the studied GCSOs had KIs with sufficient knowledge on the subject matter under investigation. It also shows that such KIs have sufficient education that can be used to enhance labour productivity in terms of innovation activities.

\subsection{Resources Capability of GCSOs for Innovations Dissemination to PC- Sos}

\section{MoCU resources factor assessment}

The study findings revealed existence of some resources at MoCU (Table 1). Technically, given such resources, one would argue that it is relatively able to disseminate innovations to PCSos. Nevertheless, study participants rated MoCU as poor in terms of resources for facilitating innovations dissemination to PCSos (Table 1). The KIs findings show that available financial resources were limited and mainly utilized to cover operational costs that include examination expenses, electricity and water bills, stationeries, classrooms and offices renovation, part-time lecturers' expenses, etc. Similarly, lack of practical innovation skills and training to personnel was revealed. One of the KIs said that:

"Two perspectives exist; first we have staff (Yes) but who are lacking the necessary skills to initiate innovations. Secondly, the executives seem not to bother about this that is why we lack trained staff especially on innovations dissemination to PCSos" (KI 1, MoCU, Feb., 2018).

The findings further, showed that the technological and physical resources available were not fully utilized for innovation activities. ICTs laboratory, website and efficient internet access connected to the national optic fibre had not been tailored to enable innovation dissemination to PCSos. One of the key physical resources; the Co-operative Entrepreneurship and Innovation Centre (CEIC) was reported to be highly under resourced in terms of financing, personnel-having only the coordinator and lacking facilities such as vehicles, innovation incubators, dissemination unit, etc. The CEIC was seen by $\mathrm{MoCU}$ as an income generating source than innovation facilitator. One of the KIs claimed that:

"Instead of funding and utilizing CEIC for innovations design and dissemination, it is considered by the management as an income generating facility" (KI 2, MoCU, Feb., 2018). 
Table 1. MoCU resources capability attributes

\begin{tabular}{|c|c|c|c|}
\hline Attributes & Summary of the key findings & $\begin{array}{l}\text { Attribute } \\
\text { rating }\end{array}$ & $\begin{array}{l}\text { Reasons for the } \\
\text { rating }\end{array}$ \\
\hline $\begin{array}{l}\text { Resources } \\
\text { availability }\end{array}$ & $\begin{array}{l}\text { Human resources: reasonable } \\
\text { number (154 academic staff) is } \\
\text { available. Financial resources: } \\
\text { Some funds from internal sources e.g. } \\
\text { tuition fee, house rent, consultancies } \\
\text { etc, government and donor agencies } \\
\text { were present. Mainly used to cover } \\
\text { operational costs and non-innovation } \\
\text { expenses. Technological resources: } \\
\text { modern ICTs laboratory, ICT } \\
\text { department, website, internet } \\
\text { connected computers exist. Physical } \\
\text { resources: libraries, co-operative } \\
\text { entrepreneurship \& innovation centre, } \\
\text { radio unit, regional centres, } \\
\text { correspondence/distance education } \\
\text { department exist. }\end{array}$ & $\begin{array}{l}\text { Resources } \\
\text { availability } \\
\text { for } \\
\text { innovations } \\
\text { dissemina- } \\
\text { tion is } \\
\text { poor. }\end{array}$ & $\begin{array}{l}\text { No considerable } \\
\text { resources were } \\
\text { specifically allocated } \\
\text { and or utilized for } \\
\text { innovations } \\
\text { dissemination to } \\
\text { PCSos. }\end{array}$ \\
\hline $\begin{array}{l}\text { Determination } \\
\text { to prioritize } \\
\& \text { utilize } \\
\text { resources for } \\
\text { innovation }\end{array}$ & $\begin{array}{l}\text { Currently not determined to prioritize } \\
\text { and utilize resources for innovation } \\
\text { dissemination. The strategic } \\
\text { document misses clear innovations } \\
\text { implementation and dissemination } \\
\text { strategies. Innovation policy was as } \\
\text { well missing. }\end{array}$ & Poor & $\begin{array}{l}\text { Not determined at } \\
\text { financing innovation. }\end{array}$ \\
\hline $\begin{array}{l}\text { Innovation } \\
\text { incentives } \\
\text { available }\end{array}$ & $\begin{array}{l}\text { Limited innovation incentives are in } \\
\text { place as there were no innovation } \\
\text { prizes, competitions, bonuses and the } \\
\text { like. Few available ones include an } \\
\text { incentive process embedded into } \\
\text { academic staff promotion system } \\
\text { requiring one to produce a patented } \\
\text { material or innovation to score some }\end{array}$ & Poor & $\begin{array}{l}\text { No inclusive } \\
\text { incentive systems } \\
\text { and the few available } \\
\text { were too meagre. } \\
\text { There were also } \\
\text { some bureaucratic } \\
\text { hurdles in accessing } \\
\text { some incentives. }\end{array}$ \\
\hline
\end{tabular}




\begin{tabular}{|c|c|c|c|}
\hline Attributes & Summary of the key findings & $\begin{array}{l}\text { Attribute } \\
\text { rating }\end{array}$ & $\begin{array}{l}\text { Reasons for the } \\
\text { rating }\end{array}$ \\
\hline & $\begin{array}{l}\text { However, there was no any registered } \\
\text { patented material at the time of the } \\
\text { study. Moreover, a royalty of } 5 \\
\text { percent of the } 60 \text { percent of the } \\
\text { consultancy fee budget awarded to an } \\
\text { individual or team managed to } \\
\text { successfully secure and register a } \\
\text { fundable assignment. Others include } \\
\text { limited competitive fund for small } \\
\text { scale research projects targeting } \\
\text { junior researchers where winning } \\
\text { proposals are awarded TZS one } \\
\text { million each. Two publication avenues } \\
\text { were also available for free to staff. } \\
\text { No formal innovation dissemination } \\
\text { reward system. }\end{array}$ & & \\
\hline $\begin{array}{l}\text { Influence of } \\
\text { external } \\
\text { factors on } \\
\text { innovation } \\
\text { resources }\end{array}$ & $\begin{array}{l}\text { Government declining funding has } \\
\text { affected resources availability. In the } \\
\text { years } 2015,2016 \text { and } 2017 \text {, the } \\
\text { organization got no funding in form of } \\
\text { other charges (OCs) from the } \\
\text { government. No clear innovation } \\
\text { resources policy-neither national STI } \\
\text { policy nor other policies were clear on } \\
\text { resources availability and commitment } \\
\text { for innovations dissemination to } \\
\text { PCSos. }\end{array}$ & High & $\begin{array}{l}\text { Reduced resources } \\
\text { availability. }\end{array}$ \\
\hline
\end{tabular}

Note: Organization resources capability in ID to PCSos rating:

$1=$ Very Poor, $2=$ Poor, $3=$ Fair, $4=$ Good/High, $5=$ Very Good

(criteria applied in all studied GCSOs)

Influence of other factors on MoCU resources capability. The study revealed that MoCU was not determined at prioritizing and utilizing resources for innovations dissemination to PCSos. Contrary to the KIs results, FGDs participants expressed concern that despite financial limitation innovation was not among MoCU's priorities. They expressed concern that MoCU was not determined at financing innovation activities as it did not feature in its budget items. One FGD participant said that:

"Despite financial constraints, if $M o C U$ was real pro-innovations, it could not fail to allocate at least one percent of its internally generated revenues for innovation undertakings" (FGD1, MoCU, Feb. 2018). 
Equally, there were limited innovation incentives that included some financial incentives. However, study participants expressed concerns in terms of bureaucracies in securing the reward especially after the money is deposited in the institution account (Table 2). Some financial incentives were also noted to be too meagre to undertake genuine innovative/research activities. Cessation of government financing to some development activities was also reported to have affected its funds ability to facilitate innovations dissemination to PCSos.

TCDC resources factor assessment. The study established that TCDC has some resources strength ranging from human, financial, technological and physical resources (Table 2). It was however, revealed that since its establishment in 2013, TCDC has not been able to mobilize sufficient resources especially funding to enable innovations dissemination to PCSos. One of the KIs said that:

"Little financial resources available have been used to put in place necessary working tools and thus done little on innovation aspects" (KI 1, TCDC, Feb. 2018).

The organization was also found to have not sufficiently directed and utilized other available resources such as personnel, physical resources and others for innovation dissemination activities. This was verified by another KI who emphasized that:

"Many co-operative stakeholders especially PCSos are unfamiliar to TCDC and or its innovations" (KI 2, TCDC, Feb. 2018).

This implies that TCDC has not yet taken sufficient efforts to invest on its available resources at ensuring organization publicity and importantly innovations disseminations to PCSos.

Influence of other factors on TCDC resources capability. The study revealed that resources prioritization and utilization for innovation activities was not among TCDC key concerns. Equally, there were no formal incentive systems to reward innovation activities. Moreover, the government's requirement to its organizations, TCDC inclusive, to finance most of its activities themselves, employment freezing at the co-operative sector and unclearly defined and communicated STI policy has compromised its ability to serve co-operatives (Table 2).

VETA resources factor assessment. The findings show that despite some resources existence at VETA (Table 3), it was ranked poor in terms of resources availability for innovations dissemination to PCSos. The available personnel mainly focused on conducting curriculum based vocational education and trainings and funds were mainly directed at covering operational costs and not at innovations dissemination activities. One of the KIs claimed that:

"Innovation activities in VETA has all along not been supported through a dedicated funding or financial allocation" (KI 1, VETA, Dec. 2017).

Findings further showed that available technological and physical resources such as computers, training machines/equipments, laboratories, workshops, etc were utilized for innovations design e.g. excavators, fish traps, eggs hatching incubators and other designs that were limited for students trainings and showcasing only i.e. were not commercialized. None were disseminated to PCSos for the reason that resources constraints mainly limited government funding has been compromising its capability to disseminate innovations. Moreover, much of the technological and 
Table 2. TCDC resources capability attributes

\begin{tabular}{|c|c|c|c|}
\hline Attributes & Summary of the key findings & $\begin{array}{l}\text { Attribute } \\
\text { rating }\end{array}$ & $\begin{array}{l}\text { Reasons for the } \\
\text { rating }\end{array}$ \\
\hline $\begin{array}{l}\text { Resources } \\
\text { availability }\end{array}$ & $\begin{array}{l}\text { Human resources: reasonable } \\
\text { personnel ( } 800 \text { country wide) at head } \\
\text { office, regional and district levels. } \\
\text { Financial resources: The } \\
\text { organization gets funding from the } \\
\text { central government. Internal sources } \\
\text { e.g. fees charged on co-operatives, } \\
\text { donor support, etc exists. } \\
\text { Technological resources: the } \\
\text { organization has computers and } \\
\text { internet connectivity (at head office } \\
\text { only); none at regional or district } \\
\text { levels. Physical resources: The } \\
\text { physical resources include office } \\
\text { premise (head office has acquired own } \\
\text { land for office use) and some vehicles. }\end{array}$ & $\begin{array}{l}\text { Resources } \\
\text { availability } \\
\text { for } \\
\text { innovations } \\
\text { dissemina- } \\
\text { tion is } \\
\text { poor. }\end{array}$ & $\begin{array}{l}\text { Not much of its } \\
\text { resources were } \\
\text { specifically allocated } \\
\text { or utilized for } \\
\text { innovations } \\
\text { dissemination to } \\
\text { PCSos. }\end{array}$ \\
\hline $\begin{array}{l}\text { Determination } \\
\text { to prioritize } \\
\& \text { utilize } \\
\text { resources for } \\
\text { innovation }\end{array}$ & $\begin{array}{l}\text { Resources prioritization and } \\
\text { utilization for innovation } \\
\text { dissemination to PCSos is not among } \\
\text { TCDC key concerns. Its strategic } \\
\text { document misses clear plans on } \\
\text { innovations dissemination to PCSos. } \\
\text { The innovation policy was also } \\
\text { missing. }\end{array}$ & Poor & $\begin{array}{l}\text { Most resources were } \\
\text { directed to } \\
\text { non-innovation } \\
\text { activities. }\end{array}$ \\
\hline $\begin{array}{l}\text { Innovation } \\
\text { incentives } \\
\text { available }\end{array}$ & $\begin{array}{l}\text { No formal innovation incentive system } \\
\text { to reward innovation dissemination } \\
\text { activities is in place. }\end{array}$ & Poor & $\begin{array}{l}\text { Missing formal } \\
\text { incentive systems. }\end{array}$ \\
\hline $\begin{array}{l}\text { Influence of } \\
\text { external } \\
\text { factors on } \\
\text { innovation } \\
\text { resources }\end{array}$ & $\begin{array}{l}\text { Government employment freezing and } \\
\text { declining financing has affected } \\
\text { resources availability. STI policy } \\
\text { insufficiently communicated and } \\
\text { translated into practice. }\end{array}$ & High & $\begin{array}{l}\text { Reduced human and } \\
\text { financial resources } \\
\text { availability. }\end{array}$ \\
\hline
\end{tabular}


physical resources in place were found to be outdated while others were not operating. One of the KIs indicated that:

"Most of our technological resources are old-fashioned making us lagging behind in terms of science and technology including innovations designs and dissemination" (KI 2, VETA, Dec. 2017).

This implies that despite some technological and physical resources availability in VETA, most of them are not in desired standards to be effectively utilized for innovation activities.

Influence of other factors on VETA resources capability. The study revealed that VETA was fairly determined at prioritizing and utilizing resources for innovation activities for the reasons that it has designed some for training students and showcasing. Equally, most innovations were not commercialized and mainly emanate from individual staff efforts than organization's efforts. Likewise, lack of formal incentive systems to reward innovation activities and declining government financing to the organization were reported to be affecting its ability to develop and disseminate innovations (Table 3).

Table 3. VETA resources capability attributes

\begin{tabular}{|c|c|c|c|}
\hline Attributes & Summary of the key findings & $\begin{array}{l}\text { Attribute } \\
\text { rating }\end{array}$ & $\begin{array}{l}\text { Reasons for the } \\
\text { rating }\end{array}$ \\
\hline $\begin{array}{l}\text { Resources } \\
\text { availability }\end{array}$ & $\begin{array}{l}\text { Human resources: the organization } \\
\text { has reasonable personnel ( } 665 \\
\text { technical staff) working in } 28 \text { training } \\
\text { centres throughout the country. } \\
\text { Financial resources: It solicits } \\
\text { funds from the central government, } \\
\text { the industries owners through Skills } \\
\text { Development Levy (SDL). Other } \\
\text { sources include fees charged to } \\
\text { students (short-term and long term } \\
\text { courses) as well as from donor } \\
\text { agencies. Technological resources: } \\
\text { the available technological resources } \\
\text { includes training } \\
\text { machines/equipments, computers, } \\
\text { internet connectivity, laboratories and } \\
\text { workshops. Physical resources: } \\
\text { The physical resources include } \\
\text { premises for office and training use, } \\
\text { libraries, vehicles and classrooms. }\end{array}$ & $\begin{array}{l}\text { Resources } \\
\text { availability } \\
\text { for } \\
\text { innovations } \\
\text { dissemina- } \\
\text { tion is } \\
\text { poor. }\end{array}$ & $\begin{array}{l}\text { No resources were } \\
\text { specifically allocated } \\
\text { for innovations } \\
\text { dissemination to } \\
\text { PCSos. However, } \\
\text { some resources were } \\
\text { used for innovations } \\
\text { designs that were } \\
\text { limited for students } \\
\text { training and } \\
\text { showcasing. }\end{array}$ \\
\hline
\end{tabular}




\begin{tabular}{llll}
\hline Attributes & Summary of the key findings & $\begin{array}{l}\text { Attribute } \\
\text { rating }\end{array}$ & $\begin{array}{l}\text { Reasons for the } \\
\text { rating }\end{array}$ \\
\hline $\begin{array}{l}\text { Determination } \\
\text { to prioritize has designed some innovations but } \\
\text { none have been disseminated to }\end{array}$ & Medium & $\begin{array}{l}\text { Limited resources } \\
\text { specially funding. }\end{array}$ \\
$\begin{array}{l}\text { PCSources for } \\
\text { innovation }\end{array}$ & $\begin{array}{l}\text { and training students only, it has } \\
\text { devised own innovation policy (2014) } \\
\text { and a strategic plan document which } \\
\text { explicitly stipulates on innovation }\end{array}$ & & \\
& $\begin{array}{l}\text { undertakings. The documents } \\
\text { however were largely unimplemented. }\end{array}$ & & \\
$\begin{array}{l}\text { Innovation } \\
\text { incentives } \\
\text { available }\end{array}$ & $\begin{array}{l}\text { No formal incentive/reward system } \\
\text { for encouraging innovations } \\
\text { dissemination activities was in place. }\end{array}$ & Poor & $\begin{array}{l}\text { Formal incentive } \\
\text { system missing }\end{array}$ \\
$\begin{array}{l}\text { Influence of } \\
\text { factornal } \\
\text { innovation } \\
\text { resources }\end{array}$ & $\begin{array}{l}\text { Declining government financing to } \\
\text { VETA has affected resources }\end{array}$ & High & Reduced VETA \\
availability. & & \\
\hline
\end{tabular}

SIDO resources factor assessment. Findings in SIDO revealed some resources availability (Table 4). Nevertheless, SIDO was rated as poor in terms of resources ability for innovations dissemination to PCSos. Available funding was mainly used to cover operational costs and other non-innovation related activities e.g. office renovations and setting new centres. Personnel were mainly utilized to undertake conventional trainings to SMEs, limited products development on demand basis e.g. hides processing, machines fabrication, spare parts and other related duties. Available technological tools e.g. computers and machines were observed to be old and obsolete and some key physical resources e.g. premises were hired to private owners. Most other facilities e.g. machines and equipments were old and manual. One of the KIs emphasized that:

"SIDO has been suffering from inadequate investment in innovation technologies advancement, making it unable to cope with the influx of imported low price products and services" (KI 1, SIDO, Dec. 2017).

As a result most of the innovations were generated from private operators who have hired SIDO premises. DFID (2014) found that the main relevant structures in Tanzania for implementing innovations particularly SIDO strongly lack resources mainly funding to enhance innovation activities. Some few innovations e.g. modern milling machine motors and other designs were found to be outsourced for a fee from technology suppliers such as the Centre for Agricultural Mechanization and Rural Technology (CARMATEC) and Tanzania Engineering and Manufacturing Design Organization (TEMDO) and others. One KI affirm that:

"Our regional centres are manned by qualified managers but lacking skilled artisans to design and disseminate innovations" (KI 2, SIDO, Dec. 2017). 
This shows the lack of skilled personnel in most regional centres is likely to affect SIDO's ability to fully engage in innovation activities.Limited facilities however were available for innovation activities, the key one located at SIDO Vingunguti office in Dar es Salaam, with an innovation incubator where novel ideas from SMEs and other individuals are nurtured, developed and financed through a special innovation programme. No PCSo however, was found to have benefited from the innovation incubation services. Other regional offices miss such facility.

Influence of other factors on SIDO resources capability. SIDO scored poor in terms of its determination to prioritize and utilize resources for innovation activities due to unimplemented plans and focusing more on non-innovation related activities. Moreover, it lacks formal innovation incentives system. Likewise, lack of practical implementation of STI policy and linkages to other strategies like industrialization agenda has contributed to SIDO's inability to innovate (Table 4).

Table 4. SIDO resources capability attributes

\begin{tabular}{|c|c|c|c|}
\hline Attributes & Summary of the key findings & $\begin{array}{l}\text { Attribute } \\
\text { rating }\end{array}$ & $\begin{array}{l}\text { Reasons for the } \\
\text { rating }\end{array}$ \\
\hline $\begin{array}{l}\text { Resources } \\
\text { availability }\end{array}$ & $\begin{array}{l}\text { Human resources: personnel are } \\
\text { spread throughout the country (about } \\
275 \text { professional staff). Financial } \\
\text { resources: It gets funds from the } \\
\text { central government. Internal sources } \\
\text { of fund include charges from trainings } \\
\text { offered, services and or equipments } \\
\text { sales and premise rent. Donor support } \\
\text { is another source. Technological } \\
\text { resources: some old } \\
\text { machines/equipments are available. } \\
\text { Workshops, computers, internet } \\
\text { connectivity mainly at head office and } \\
\text { some regional offices exist. Physical } \\
\text { resources: Existing physical } \\
\text { resources include land for office use } \\
\text { and for renting under the build and } \\
\text { rent programme and an innovation } \\
\text { incubator-Dar es Salaam office. }\end{array}$ & $\begin{array}{l}\text { Resources } \\
\text { availability } \\
\text { for } \\
\text { innovation } \\
\text { dissemina- } \\
\text { tion is } \\
\text { poor. }\end{array}$ & $\begin{array}{l}\text { No considerable } \\
\text { human, financial, } \\
\text { technological or } \\
\text { physical resources } \\
\text { were specifically } \\
\text { utilized for } \\
\text { innovations } \\
\text { dissemination to } \\
\text { PCSos. }\end{array}$ \\
\hline
\end{tabular}




\begin{tabular}{|c|c|c|c|}
\hline Attributes & Summary of the key findings & $\begin{array}{l}\text { Attribute } \\
\text { rating }\end{array}$ & $\begin{array}{l}\text { Reasons for the } \\
\text { rating }\end{array}$ \\
\hline $\begin{array}{l}\text { Determination } \\
\text { to prioritize } \\
\& \text { utilize } \\
\text { resources for } \\
\text { innovation }\end{array}$ & $\begin{array}{l}\text { SIDO is not determined at prioritizing } \\
\text { and utilizing resources for innovations } \\
\text { dissemination e.g. most funding were } \\
\text { used for non-innovation related } \\
\text { activities. Some innovation plans were } \\
\text { apparent in its strategic plan } \\
\text { document but remain unimplemented. } \\
\text { The innovation policy was also } \\
\text { missing. }\end{array}$ & Poor & $\begin{array}{l}\text { Focus more on } \\
\text { conventional } \\
\text { trainings than } \\
\text { innovation aspects. }\end{array}$ \\
\hline $\begin{array}{l}\text { Innovation } \\
\text { incentives } \\
\text { available }\end{array}$ & $\begin{array}{l}\text { No formal innovation incentives are in } \\
\text { place. }\end{array}$ & Poor & $\begin{array}{l}\text { Formal incentive } \\
\text { system lacking. }\end{array}$ \\
\hline $\begin{array}{l}\text { Influence of } \\
\text { external } \\
\text { factors on } \\
\text { innovation } \\
\text { resources }\end{array}$ & $\begin{array}{l}\text { National STI policy and other } \\
\text { strategies e.g. industrialization } \\
\text { agenda not clearly translated and } \\
\text { communicated to be grabbed as an } \\
\text { opportunity to SIDO. There is also } \\
\text { inadequate funding. }\end{array}$ & High & $\begin{array}{l}\text { Reduced SIDO's } \\
\text { capability to } \\
\text { innovate. }\end{array}$ \\
\hline
\end{tabular}

\section{TaCRI resources capability assessment}

TaCRI assessment of its resources strength revealed that most of its resources were allocated and utilized for innovation activities (Table 5). It utilizes its personnel and funds in designing and disseminating improved coffee seedlings to farmers and PCSos throughout coffee growing areas of Tanzania. Its technological resources including modern laboratory for soil and tissue culture experiments and physical resources e.g. land, piloting/experimentation plots, vehicles and others were utilized for developing and disseminating improved coffee seedlings to farmers and PCSos.

Influence of other factors on TaCRI resources capability. TaCRI was ranked as good in terms of determination to prioritize and utilize resources for innovation activities since innovation is part of its daily routine and core activities. It has also clear formal incentive system with several attractive packages that was reported to have positively encouraging innovations dissemination (Table 5). Nevertheless, the government directives through the minister responsible for Agriculture, Livestock and Fisheries to supply improved coffee seedlings to farmers and PCSos free of charge with unfulfilled pledge to subsidize the organization and declining government funding to TaCRI have amounted to declining resources for innovations dissemination (Table $5)$. 
Table 5. TaCRI resources capability attributes

\begin{tabular}{|c|c|c|c|}
\hline Attributes & Summary of the key findings & $\begin{array}{l}\text { Attribute } \\
\text { rating }\end{array}$ & $\begin{array}{l}\text { Reasons for the } \\
\text { rating }\end{array}$ \\
\hline $\begin{array}{l}\text { Resources } \\
\text { availability }\end{array}$ & $\begin{array}{l}\text { Human resources: reasonable } \\
\text { technical personnel (65) employed } \\
\text { under the organization policy to have } \\
\text { a lean but efficient staff. Financial } \\
\text { resources: It solicits funds from the } \\
\text { government (about } 13 \% \text { of total } \\
\text { annual budget). Main source of } \\
\text { funding is from stakeholders i.e. coffee } \\
\text { growers. It also gets substantial donor } \\
\text { aid mainly from the European Union. } \\
\text { Internal sources include selling coffee, } \\
\text { seedlings and services offered. } \\
\text { Technological resources: modern } \\
\text { laboratories, website, internet } \\
\text { connectivity and computers exist. } \\
\text { Physical resources: Physical } \\
\text { resources include land (254 hectares), } \\
\text { vehicles, coffee farms, } \\
\text { piloting/experiment plots and coffee } \\
\text { nurseries. }\end{array}$ & $\begin{array}{l}\text { Resources } \\
\text { availability } \\
\text { for } \\
\text { innovation } \\
\text { dissemina- } \\
\text { tion is } \\
\text { good. }\end{array}$ & $\begin{array}{l}\text { Most of the resources } \\
\text { in place were utilized } \\
\text { for innovations } \\
\text { dissemination } \\
\text { (PCSos inclusive) }\end{array}$ \\
\hline $\begin{array}{l}\text { Determination } \\
\text { to prioritize } \\
\& \text { utilize } \\
\text { resources for } \\
\text { innovation }\end{array}$ & $\begin{array}{l}\text { Innovation activities have been part } \\
\text { of TaCRI daily routines and hence } \\
\text { core activities. Determined at } \\
\text { prioritizing and using resources on the } \\
\text { same. TaCRI's strategic plan } \\
\text { document clearly stipulates plans for } \\
\text { innovations design and dissemination. }\end{array}$ & Good & $\begin{array}{l}\text { Focused at financing } \\
\text { and implementing } \\
\text { innovations }\end{array}$ \\
\hline
\end{tabular}




\begin{tabular}{|c|c|c|c|}
\hline $\begin{array}{l}\text { Innovation } \\
\text { incentives } \\
\text { available }\end{array}$ & $\begin{array}{l}\text { Formal innovation incentive systems } \\
\text { were in place including financial } \\
\text { bonues, staff promotion based on } \\
\text { innovations developed and } \\
\text { disseminated, financing innovative } \\
\text { publications where up to } 500 \text { US } \\
\text { dollars were available per each } \\
\text { publication. Others include staff } \\
\text { promotion to a higher rank based on } \\
\text { innovations performance and } \\
\text { recognizing innovators contributions } \\
\text { in special TaCRI manuals. Existing } \\
\text { incentives have positively encouraged } \\
\text { innovations dissemination. About } 23 \\
\text { improved coffee varieties have been } \\
\text { disseminated to farmers and PCSos in } \\
\text { Tanzania. }\end{array}$ & Good & $\begin{array}{l}\text { The incentives have } \\
\text { positively enabled } \\
\text { innovations } \\
\text { dissemination. }\end{array}$ \\
\hline $\begin{array}{l}\text { Influence of } \\
\text { external } \\
\text { factors on } \\
\text { innovation } \\
\text { resources }\end{array}$ & $\begin{array}{l}\text { Unfulfilled government directives to } \\
\text { subsidize TaCRI and declining } \\
\text { government funding have amounted } \\
\text { to declining resources availability for } \\
\text { innovations dissemination. Financing } \\
\text { fell from previous TZS } 500 \mathrm{~m} \text { in } 2005 \\
\text { to } 150 \mathrm{~m} \text { in } 2015 \text { and sharply to TZS } \\
4 \mathrm{~m} \text { in } 2016 \text { and } 2 \mathrm{~m} \text { in } 2017 \text {. }\end{array}$ & High & $\begin{array}{l}\text { Reduced resources } \\
\text { availability for } \\
\text { innovations } \\
\text { dissemination. }\end{array}$ \\
\hline
\end{tabular}

\subsection{Discussion}

\section{GCSOs resources factor assessment for innovations dissemination to PCSos}

There was availability of resources in all studied GCSOs whereby some could be directed at innovations activities. Nevertheless, in most GCSOs except TaCRI resources were directed at covering non innovation related activities. TaCRI was able to utilize some of its funds and other resources for innovations dissemination because apart from innovation being among its core mandate, it was not too reliant on government to finance its activities. Most of the innovation funding came mainly from stakeholders contributions i.e. coffee growers as the main source, donors and own sources. The implication drawn here is that as most funding came from the stakeholders, they have always been demanding value for the money invested and this therefore explains TaCRI's activeness in utilizing available resources for innovations dissemination. On average, government financing to TaCRI between the years 2007-2017 was only $13 \%$ of its total annual budget, unlike other GCSOs which stood at more than $75 \%$. It was revealed that in most cases, government financing to GCSOs was not fulfilled as planned due to financial limitation. Osakwe \& Moussa (2017) found that while governments have a major role to play in promoting innovation, it is not its responsibility alone. Organizations also have important role to play. 
This implies that GCSOs are equally obliged to ensure sufficient innovation finances through own sources to reduce too much reliance on government.

Availability of some human resources featured in all studied GCSOs. However, the majority of them except TaCRI were not capacitated by their GCSOs with adequate innovation skills and trainings. This shows that as most GCSOs are not equipped with such necessary innovation techniques they are likely to be incapable to successfully undertake significant innovation activities. This is because, usually innovation skills and trainings are among the key innovation inputs in organizations and thus its lacking translates into poor innovation performance. Oyelaran-Oyeyinka (2014) and van Uden et al. (2017) established that public organizations in Sub Saharan Africa (SSA) are suffering from substantial lack of human competencies and skills due to inadequate investment on the same. Usually, employees need to be trained and educated before they can have a positive impact on the innovation process (Shipton, West, Dawson, Birdi \& Patterson, 2006; Texeira \& Tavares-Lehman, 2014). This implies that trainings like on-job/off-job innovation trainings, seminars, conferences, etc are crucial at enhancing personnel capabilities to disseminate innovations. Moreover, some technological and physical resources were available in all GCSOs but only those of TaCRI were fully dedicated for innovations dissemination to PCSos. This shows that resources availability alone is not sufficient to enable innovations dissemination. Thus, other attributes including willingness and or determination to implement desired innovation activities are equally important.

\section{Influence of other factors on GCSOs resources ability to disseminate innovations}

Innovation resources prioritization and or utilization in the studied GCSOs. The study established that most GCSOs were not determined at prioritizing and utilizing resources for innovations dissemination to PCSOs. Several reasons including unwillingness by GCSOs to finance innovation activities and limited resources were established by study participants. Some participants expressed concern that resources were too little to be directed for innovation activities and that their GCSOs had not got such resources from the government specifically for innovation activities. The implication drawn here is that there was a misconception among some study participants on innovation resources, in the sense that for innovation activities to be possible there must be a special innovation package branded "innovation resources" that should come from the government to GCSOs. This was so because, some resources like personnel, finances and others were available but unutilized for innovation activities. Thus, the findings implied that apart from unwillingness by some GCSOs executives to prioritize and or utilize resources for innovation activities as earlier postulated in this study, the misconception on innovation resources also contributed to their incapability to disseminate innovations to PCSos.

Innovation incentives for motivating staff to disseminate innovations to PCSos. This study revealed that innovation incentives in most of the studied GCSOs were not only inadequate as earlier assumed in this paper, but were also unpromising and missing in some organizations. In most GCSOs except TaCRI and to a lesser extent MoCU, there were no formal incentive systems for rewarding innovation dissemination activities. There were also some incidences where available incentives were claimed to be too little and difficult to acquire in terms of associated bureaucratic hurdles. The Carrot and Stick Theory emphasize that employees should be rewarded for them to elicit desired behaviours. This means that for them to be able to actively partici- 
pate in innovation dissemination activities, they should be rewarded with some incentives such as innovation prizes, competitions, recognition, training opportunities, promotions and others. This implies that the failure by most GCSOs to facilitate innovations dissemination to PCSos partly result from the lack of incentives from the government or GCSOs to activate its resource base particularly personnel to elicit innovation activities. The negative incentives in form of reinforcement e.g. special directives from the government or GCSOs boards demanding them to innovate were also missing. Moussa, McMurray \& Muenjohn (2018) found that governments around the world have repeatedly ignored the need for developing incentive systems to promote innovation in public sectors. Unlike other GCSOs, TaCRI had clear reward system that is well implemented and considered as a key activator in disseminating innovations to coffee farmers, PCSos inclusive. MoCU also had a limited form of rewarding innovation activities.

Influence of external factors on GCSOs resources capability. This study revealed that some external factors were found to affect the GCSOs resources capability to disseminate innovations to PCSos. They include government interventions such as the freezing of the new employments and unprecedented decline in government financing to GCSOs. DFID (2014) established that there has been lack of government resources commitment especially funding to enable innovation activities in Tanzania. Likewise, most GCSOs except VETA lacked own innovation policy expressing concern that the national STI policy is not sufficiently communicated and translated into GCSOs practice especially on resources availability and commitment for innovations dissemination to PCSos. Thus, the study affirms that some external factors have been affecting GCSOs resources capability to disseminate innovations to PCSos. Equally, in most GCSOs except TaCRI, there was no funding specifically allocated for innovation Research and Development $(\mathrm{R} \& \mathrm{D}) . \mathrm{R} \& \mathrm{D}$ expenditure is an important innovation input in all innovative and competitive organizations (Goedhuys et al., 2014). Most GCSOs claimed that they were not provided with R \& D funding by the government. Nevertheless, Osakwe \& Moussa (2017) show that governments in SSA, have been allocating only $0.42 \%$ of their domestic expenditure (\% of GDP) for R \& D. Studies have shown that Tanzania has been allocating only $0.25 \%$ of its domestic expenditure for R \& D against the national target of 1\% set in 1995 (DFID, 2014; World Bank, 2005). This amount is incredibly minimal to enable significant innovation activities in all government sectors. This implies that R \& D government financing to GCSOs will continue to remain significantly low unless sufficient funds are allocated for the same.

The contribution of the study to the body of knowledge. Based on the Resource Dependence Theory grounds, the study established existence of GCSOs resources reliance syndrome skewed on the government side, in the sense that, most GCSOs feel they were unable to facilitate innovation activities because they were not provided with innovation resources from the government. Nevertheless, the study revealed that some resources were available but unutilized for innovation activities. This then was taken care by the second theory i.e. the Carrot \& Stick Theory, in that perhaps there were no incentives to reinforce GCSOs executives and personnel to utilize available resources for innovations dissemination to PCSos. But again, the study identified some cases where incentives were available but personnel were not motivated towards such incentives (outcome based) because of some bureaucratic hurdles to acquire them, too meagre incentives and lack of clear incentive systems. Thus, this study contributes to the C \& $\mathrm{S}$ Theory 
in the sense that for incentives to result into desirable outcomes they should not only focus on the ends (outcome based) but on means (process) as well.

\section{Study Limitations and Areas for Further Research}

As is with the majority of studies, the design of the current study is subject to some limitations. The first limitation concerns the type of research design used i.e. case study research design. The case study has long been stereotyped as a weak sibling among social science methods. Case studies have continued to be denigrated as having insufficient precision (i.e. quantification), objectivity or rigor (Yin, 2003). To address this weakness multiple case studies approach was applied. The approach is considered to increase methodological rigor as it strengthens the precision, validity and reliability of findings (Miles and Huberman, 1994). The second limitation is that this work was conducted at a time when some key GCSOs i.e. the Tanzania Co-operatives Development Commission (TCDC) and Moshi Co-operative University (MoCU) were still readjusting from major re-organization. This is due to the fact that TCDC was established in 2013 following the transformation of the former Co-operative Department in Tanzania and MoCU was established in 2014 following the upgrading of the former Moshi University College of Cooperative and Business Studies (MUCCoBS) itself having been transformed from the Moshi Co-operative College in 2004. Thus, some organisational transformation events and or changes that may in one way or another influenced organisations' resources capability for innovations dissemination to PCSos are likely to have continued to happen beyond the study period and coverage. The researchers therefore may not claim to have seen, cover and present all of the facts required for this study at its entirety through to their conclusion. A similar study is therefore recommended after some time in future to assess the resources capability of such organizations in dissemination of innovations to PCSos. The third one is that this study was limited to GCSOs only despite the fact that there are other member-based and private organizations that support co-operatives in Tanzania. A more inclusive study covering and comparing other co-operative supporting organizations is advised in future to establish their resources capability for dissemination of innovations to PCSos.

\subsection{Conclusions and Recommendations}

This study concludes that most GCSOs were not determined at prioritizing and utilizing resources for innovations dissemination to PCSos. It is advised that the GCSOs executives should ensure sufficient resources commitment and its utilization to enable innovations dissemination to PCSos. The study further concludes that lack of incentives to support innovation activities amongst GCSOs executives and personnel has been hindering dissemination of innovations to PCSos. Most GCSOs lack formal and comprehensive incentive systems to reward innovation activities. In that case, GCSOs executives should establish and implement clear incentive systems to reward innovation dissemination activities. The incentive systems should include inclusive rewards e.g. innovation trainings, prizes, competitions, financial rewards, salary hikes based on innovation activities done, recognition of innovators and others. The government through GCSOs boards should do the same to motivate executives so that trickledown effect can be attained. This is because, findings established incidences where innovation dissemination activities were neither amongst GCSOs priorities nor rewarded e.g. through provision of innovation skills. Equally, 
some negative reinforcements e.g. directives from the GCSOs boards to the executives and from executives to personnel demanding them to implement innovations dissemination to PCSos, as part of their performance appraisal system are suggested. It is also concluded that some external factors including government freezing of employment at the co-operative sector and declining government funding commitment to GCSOs have affected GCSOs resources availability to enable innovations dissemination to PCSos. Then GCSOs should strive to minimize the resultant negative effect from such factors through mobilizing more internal resources to arrest the situation. Other external factors include unimplemented government directives e.g. failure to subsidize improved coffee seedlings production and dissemination as promised at TaCRI and uncoordinated and poorly translated national STI policy to GCSOs. It is recommended that GCSOs executives should strive to mobilize more internal resources to cover such unimplemented gaps. Moreover, the GCSOs should strive to derive and translate the national STI policy into their context to come up with own and practicable innovation policies.

\section{Acknowledgement}

The authors wish to extend their appreciation to the government of Tanzania through the Moshi Co-operative University (MoCU) for funding this study.

\section{References}

Barasa, L., Knoben, J., Vermeulen, P., Kimuyu, P. \& Kinyanjui, B. (2017). Institutions, resources and innovation in East Africa: A firm level approach. Elsevier Research Policy, 46(1), 280-291.

Barney, J. (1991). Firm resources and sustained competitive advantage. Journal of Management, 17 (1), 99-120.

Bekkers, V., Edelenboss, J. \& Steijen, B. (2011). Innovation in the public sector: Linking capacity and leadership. London, England: Houndmills, Palgrave McMillan.

Bengtsson, P. (1999). Multiple case studies-not just more data points?. Term paper in graduate course in research methodology, Spring, p. 1-9.

Diyamett, B. \& Wangwe, S. (2006). Innovation indicators within SSA: Specific case for Tanzania. In Blankley, W., Scerri, M., Molotja, N. \& Saloojee, I. (Eds.). Measuring innovation in OECD and non-OECD countries. Selected seminar papers. HSRC Press, South Africa. p.183-199.

Borda-Rodriguez, A., Johnson, H., Shaw, L. \& Vicari, S. (2013). What makes rural co-operatives resilient in developing countries? Understanding rural resilience in Malawi: A pilot study, UK Co-operative College, Manchester, 20 pp.

Bowring, J. (Eds.) (1962). The works of Jeremy Bentham, 11 vols. Edinburg, Scotland. $535 \mathrm{pp}$.

Bradley, S., McMullen, J., Artz, K., \& Simiyu, E. (2012). Capital is not enough: innovation in developing economies. Management Studies, 49 (4), 684-717.

Cbsemocha (2008). Classification of resources. Retrieved from http:/www.cbesmocha.com 
Chambo, S. (2018, June 5). Importance of autonomous cooperatives. Habari Leo, p. 11.

Christensen, C. M. (1997). The Innovation Dilemma: When New Technologies Cause Great Firms to Fail. Massachusetts, MA: Harvard Business School Press.

Damschroder, L., Aron, D., Keith, R., Alexander, J. \& Lowery, J. (2009). Fostering implementation of health services research findings into practice: a consolidated framework for advancing science implementation. Implementation Science, 4 (1), 1-50.

Department for International Development. (2014). Policy diagnostic report Tanzania: Innovation and growth research project. Technopolis group, UK, 46pp.

Edwards, T., Delbridge, R. \& Munday, M. (2005). Understanding innovation in SMEs: a process manifest. Technovation, 25 (1), 1119-1127.

Gaffney, M. (1967). Extractive resources and taxation. Madison, WI: University of Wisconsin Press.

George, G., Gorbishley, C., Khayesi, J., Haas, M. \& Tihanyi, L. (2016). Bringing Africa in promising directions. Academy of Management, 59 (1), 377-393.

Goedhuys, M. \& Sleuwagen, L. (2010). High growth entrepreneurship firms in Africa: A quantile regression approach. Small Business Economics, 34 (1), 31-51.

Goedhuys, M., Janz, N., \& Mohnen, P. (2014). Knowledge based productivity in low-tech industries: evidence from firms from developing countries. Industrial Corporate Change, 23 (1), $1-23$.

Grant, R. (1991). The resource-based theory of competitive advantage: implications for strategy formulation. California Management Review, 33 (3), 114-135.

Hillman, A., Withers, M. \& Collins, B. (2009). The resource dependence theory: A review. Journal of Management, 35 (6), 1404-1427.

Hixson, R. (1989). Bentham's the rationale of reward. Journal of the Rutgers University Libraries, 33(1), 1-7.

Hollander, M. \& Kadlec, H. (2015). Incentive based primary care: costs and utilization analysis. The Permanente Journal, 19 (4), 46-56.

International Co-operative Alliance. (2013). ILO and cooperatives, Coop News No. 2, 2013. Cooperatives Unit, International Labour Office (ILO), Geneva, 16pp.

Johnson, D. K. \& Lybecker, K. M. (2009). Challenges to technology transfer: A literature review of the constraints on environmental technology dissemination, Collorado College Working Paper No. 2009-07, p. 42.

Lamon, A. (2014). Three types of economic resources. Retrieved from http://www.resources/typ/

Laursen, K., Masciarelli, F. \& Prencipe, A. (2012). Regions matter: how localized social capital affects innovation and external knowledge acquisition. Organization Science, 23 (1), 177193. 
Lomas, J. (1993). Diffusion, dissemination and implementation: who should do what?. Annals of the New York Academy of Sciences, 703 (1), 223-237.

MacDougall, C. \& Fudge, E. (2001). Planning and recruiting the sample for focus groups and in-depth interviews. Qualitative Health Research, 11 (1), 117-126.

Mathew, J., Jose, P. \& Thomas, K. (2006). Organizational constraints on innovation and intrapreneurship: Insights from public sector. VIKALPA, 31(1), 49-60.

Miles, G. \& Huberman, A. (1994). Qualitative data analysis: An expanded source book. London, England: Sage.

Moussa, M., McMurray, A. \& Muenjohn, N. (2018). A conceptual framework of the factors influencing innovation in public sector organizations. The Journal of Developing Areas, 52(3), 231-240.

Murphy, D., Lyu, P., Gregg, S., Martin, G., Hockenberry, J. Coopersmith, C. ... Sevransky, J. (2016). Using incentives to improve resource utilization: a quasi-experimental evaluation of an ICU quality improvement program, Crit Care Med., 44 (1), 162-171.

Ndofor, H., Sirmon, D. \& He, X. (2015). Utilizing the firm's resources: How TMT heterogeneity and resulting fault lines affect TMT tasks. Strategic Management Journal, 36 (11), 1656-1674.

Osakwe, P. \& Moussa, N. (2017). Innovation, diversification and inclusive development in Africa. UNCTAD Research Paper No. 2, 26pp.

Osborne, S.P. (1998). Naming the beast: delivering and classifying service innovations in social policy. Human Relations, 1(51), 1133-54.

Oxford dictionary online (2001). Meaning of incentives. Retrieved from http://dictionary/oxford.org/

Oyelaran-Oyeyinka, B. (2014). The state and innovation policy in Africa. Journal of Innovation Research 8 Economic Development in Africa, 6 (5), 481-496.

Patana, P. \& Pinto, J. (2014). Examining the role of government policy on innovation. High Technology Management Research, Elsevier 25 (2), 97-107.

Pfeffer, J. \& Salancik, G. (1978). The external control of organizations: A resource dependence perspective. New York, NY: Oxford Press.

Piening, E. P. (2013). Dynamic capabilities in public organizations. Public Management Review, 15(2), 209-245.

Regnar, O., Borchgrerink, A., Lazaro, E. and Temu, A. (2002). Poverty-reducing effects of agricultural development in Tanzania. Noragric report number 10, December, 2002. Noragric Agricultural University of Norway. Retrieved from [http://www.nln.noragric.html.] site visited on $2^{\text {nd }}$ June 2018.

Restrepo, A. \& Valencia, M. (2014). Motivating employees beyond the carrot and stick techniques, AD-minister no. 24. Retrieved from http://www.scielo.go.co/

Sambua, S. \& Mghwira, D. (2014). Rapid scoping and mapping of Tanzania innovation ecosystem. Human Development Innovation Fund (HDIF), Dar es Salaam, 183pp. 
Shipton, H., West, M., Dawson, J., Birdi, K. \& Patterson, M. (2006). HRM as a predictor of innovation. HRM Journal, 16(1), 3-27.

Sirmon, D., Hitt, M., \& Ireland, R. (2007). Managing firm resources in dynamic environments to create value: looking inside the black box. Academic Management Review, 32 (1), 273-292.

Smith, M., Bursi, M., Ball, P. \& van dee Meer, R. (2008). Factors influencing an organizations ability to manage innovation: a structured literature review and conceptual model. Journal of Innovation Management, 12 (2), 634-655.

Srholec, M. (2011). A multi-level analysis of innovation in developing countries. Industrial Corporate Change, 20 (6), 1539-1569.

Stewart, D. W., Shamdasani, P. N., \& Rook, D. W. (2007). Focus groups: Theory and practice ( $2^{\text {nd }}$ ed.). Thousand Oaks, CA: Sage.

Taylor, B., Sinha, G. \& Ghoshal, T. (2011). Research methodology: A guide for researchers in management and social sciences. New Delhi, India: PHI Learning Private.

Tefera, E. (2008). Role of dairy cooperatives in stimulating innovation and market oriented smallholders development: The case of Ada'a Dairy Cooperative, Central Ethiopia (Master's dissertation). Hamaraya University, Ethiopia.

Texeira, A. \& Tavares-Lehman, A. (2014). Human capital intensity in technology based firms: Does foreign ownership matter? Research Policy, 43(1), 737-748.

Tuttle, C. A. (1927). The function of the entrepreneur. The American Economic Review, 1325 .

United Nations Conference on Trade and Development. (2015). World investment report 2015. The United Nations, Geneva. 428pp.

United Republic of Tanzania. (2006). The Cooperative reform and modernization programme (CRMP). MAFC, Dar es Salaam. 60pp.

United Republic of Tanzania. (2013). National agricultural policy 2013, MAFC, Dar es Salaam.42pp.

United Republic of Tanzania. (2016). Tanzania national budget: Speech by the minister of Agriculture, Livestock and Fisheries, Dodoma. 112pp.

van Uden, A., Knoben, J. \& Vermeul, P. (2017). Human capital and innovation in Sub Saharan countries: a firm level study. The European Journal of Social Science Research, 19(2), 103124.

World Bank (2005). Innovation in Tanzania: Insights, issues and policies, The World Bank Institute, Washington DC. p. 28.

World Bank (2006). Enhancing agricultural innovation: How to go beyond the strengthening of research systems. The World Bank, Washington DC. 116pp.

World Bank (2012). Social protection and labour strategy. World Bank, Washington DC. $56 \mathrm{pp}$. 
World Bank (2016). Doing business report. The World Bank, Washington DC.268pp.

Yin, R. K. (1994). Case study research: Design and methods. Beverly Hills, CA: Sage.

Yin, R. K. (2004). Complementary methods for research in education. Washington, DC: American Educational Research Association. 


\section{Biographies}

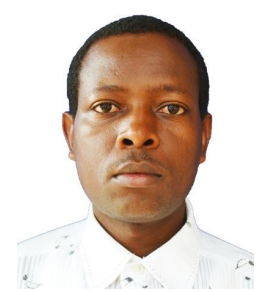

Luka S. Njau. Luka Njau is a Lecturer at the department of Community and Rural Development of Moshi Co-operative University (MoCU), Tanzania. He is currently pursuing Ph.D. studies in Rural Development at Sokoine University of Agriculture (SUA). He holds a Master of Art degree in Rural Development, a Bachelor of Science degree in Agricultural Education and Extension and a Certificate in Managing Agricultural Marketing Co-operatives (My.Coop) from International Training Centre of the International Labor Organization. He has extensive teaching and field work experience accumulated over ten years period working at the university, the community, community based organizations as well as international organizations. He teaches extension education courses, co-operative extension, adult training methodologies, participatory techniques and research methodology. His research interest includes co-operative innovations, co-operative development, rural development interventions, adult learning aspects, community economic development (CED) philosophy \& interventions and cross-cutting issues.

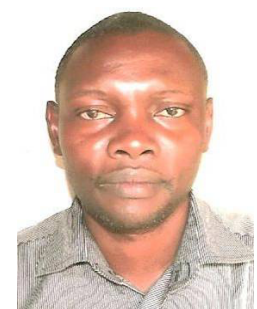

Christopher P. Mahonge. Christopher Paul Mahonge is an Associate Research Professor in the Department of Policy Planning and Management, College of Social Sciences and Humanities at Sokoine University of Agriculture, Tanzania. He is specialised on Governance of complex Social-Ecological Systems. His research experience has focused on community-based natural resources management and livelihood improvements, linkages among the state, nongovernmental and community actors and institutions, socio-economic implications of climate change, land use planning, and institutional analysis (government-based, organisation-based, and community-based formal and informal rules systems associated with governance of socialecological systems), out-scaling and hybridization of institutions, and informal politics.

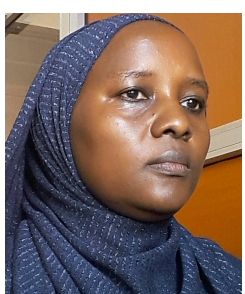

Fatihiya A. Massawe. Dr. Fatihiya A. Massawe received a Ph.D. in Rural development from the Sokoine University of Agriculture (SUA) in 2014, Postgraduate Diploma in Poverty Analysis jointly offered by ESRF, REPOA, and ISS (Netherlands) in 2009, an MSc in International Development Studies majoring in Rural Development Sociology from Wageningen University Netherlands in 2006 and BSc in Home Economics and Human Nutrition from SUA, 2000. She is currently serving as a senior lecturer at the Campus College of Social Sciences and Humanities- SUA and the head of the Department of Policy, Planning, and Management at the same College. Before joining SUA, she was working as a Community Development Officer in the Vice President Office and the Ministry of Community Development Gender and Children for 7 years. Her interest in teaching, research and consultancies focuses on Poverty analysis; Nutrition \& Gender; HIV \& Gender; energy and livelihood, adoption of technology. She has participated in many projects and published in the same area of specialization. Ms. Fatihiya is a recipient of the year2018/2019 Martha Farrell Foundation Fellowship award that foster institutionalization of initiatives against sexual harassment at workplaces.

\section{ISSN 2183-0606}

http://www.open-jim.org

http://creativecommons.org/licenses/by/3.0 